AGRO EKONOMI, Vol 31, Issue 1, June 2020, Page.1-15

DOI : http://doi.org/10.22146/ae.50004

ISSN 0215-8787 (print), ISSN 2541-1616 (online) Available at https://jurnal.ugm.ac.id/jae/

\title{
TECHNICAL EFFICIENCY OF STATE-OWNED SUGARCANE PRODUCTION IN EAST JAVA
}

\author{
M. Taufik Yusuf ${ }^{1,4^{*}}$, Jamhari $^{2}$, Irham $^{3}$ \\ 1,2,3 Department of Agricultural Socio-Economics, Faculty of Agriculture, \\ Universitas Gadjah Mada, Yogyakarta, 55281, Indonesia \\ ${ }^{4}$ PTPN XI, Surabaya, East Java, 60175, Indonesia \\ *Corresponding author: m.taufik.yusuf@gmail.com
}

Submitted: 25 September 2019; Revised: 23 December 2019;

Accepted: 22 January 2020

\begin{abstract}
This study aims to (1) identify the factors that influence the production of plant cane and ratoon cane, (2) determine the level of production efficiency of plant cane, ratoon cane, and poll, and (3) identify the factors that influence the inefficiency of plant cane and ratoon cane production. The data used was secondary data sourced from the production data for the 2017-2018 planting season with some inputs: land area, fertilizers, herbicides, labor, age of plants harvested and data of land types. From the analysis, it was revealed that (1) factors influencing the increase of plant cane production were land area, ZA fertilizer, harvest labor, and types of fields. Meanwhile, the influential factors impacting the increase of ratoon cane were land area, SP36 fertilizer, ametryn herbicide, harvest labor, type of fields, and HGU land type while estate labor, mechanization, and dummy varieties affect decreasing on it, (2) sugarcane farming was technically efficient (3) factors affecting the inefficiency for plant cane are formal education and rank levels of plant officer. However the coefficient of the formal education variable was negative and the rank level coefficient was positive. A higher level of education will increase production, but a higher rank level of plant officer will decrease it. Improving education levels can be provided by giving mentoring or the provision of courses. In ratoon cane, there was no effect of technical inefficiency. So an increase in ratoon cane production can be done by increasing the use of production inputs.
\end{abstract}

Keywords : Inefficiency; Stochastic frontier; Sugarcane; Technical efficiency

How to cite: Yusuf, M.T., Jamhari, \& Irham. 2020. Technical Efficiency of State-Owned Sugarcane Production in East Java. Agro Ekonomi, 31(1), 1-15.

\section{INTRODUCTION}

One of the main problems of the sugar industry in Indonesia is low productivity. A release from the Ministry of Agriculture shows that the sugar yield (tons of crystal/Ha) between 2011-2016 is very volatile. The sugar productivity of the private sector tends to be higher than that of the productivity of the large state-owned companies (BUMN) or the farmers (Kementerian Pertanian, 2016). State-owned company has to take a role in increasing productivity, especially for its owned-by-company sugarcane. 
Owned-by-company sugarcane is managed by the company where the land originates from the right to cultivate the land (HGU) or leased land.

Based on data from the United States Department of Agriculture (USDA) 2018 in Gideon (2019), the productivity of sugar cane plantations in Indonesia only reached 68.29 tons per hectare in 2017. This number was lower than other sugar producing countries, such as Brazil and India with productivity of 68.94 tons per hectare and 70.02 tons per hectare respectively in the same year. Low sugarcane productivity triggers an increase in sugar imports. A report from the Nusantara Sugar Community (2017) shows that the average growth of sugar cane production (tons) from 2013-2017 was minus 4.75 thousand tons/year. The declining trend of the sugarcane production should be responded by making some improvements, one of it is by improving the sugarcane management. This study aims to answer several issues related to sugarcane management, specifically related to production factors and human factors who manage the estate of sugarcane. One of sugarcane management which is emphisized is increasing the efficiency of sugarcane production.

There are many previous studies about the efficiency of sugarcane production, but generally did not investigate state-owned enterprise, for instance, the study on the efficiency of farmer sugarcane and not owned-bycompany sugarcane especially in large state-owned companies. This study mainly aims (1) to identify the factors that influence the production of plant and ratoon cane, (2) to determine the level of technical efficiency of plant cane, ratoon cane, and poll, and (3) to identify factors influencing the inefficiency of plant and ratoonc cane on owned-bycompany sugarcane plantation.

According to Tinaprilla (2011) the land area is considered the most responsive to sugarcane production. Another important variable is ZA fertilizer, manure, and other liquid fertilizers. According to Fahriyah et al. (2018) the average level of technical efficiency of sugarcane farming in the wetland was 0.8311 and in dryland was 0.7991. Meanwhile, Zainuddin \& Wibowo (2018) stated that variables affecting the inefficiency of sugarcane farming were the level of education, number of family members, farm credit dummy, and the use of bud-chip technology.

\section{METHODS}

Descriptive-analytic was applied as the basic method in this study. The secondary data sourced from the stateowned plantation company located in East Java Province were analyzed. They 
consisted of state-owned sugarcane production data from the 2017-2018 planting season with several inputs: land area, fertilizers, herbicides, labor, age of harvested plants and land type. Age, work experience, formal education, household size, and the rank level of plant officers were examined as managerial data. Plant officer is a man/woman who is responsible for managing the estate. The object of this study was the company-owned's sugarcane plantation which is managed by a plant officer. The estate was located in East Java. The total number of estate was 1,404 estate divided into 531 plant cane estate and 873 ratoon cane estate. These estates were the population of all object of this study situated in 4 sugar factories in East Java.

To find out the factors affecting sugarcane production, the equation of the stochastic production function was used and estimated by the Maximum Likelihood Estimation (MLE) method. The test was carried out by using the Frontier 4.1 program. The frontier production function model is described as (Coelli et al., 2005):

$$
\operatorname{Ln} \mathrm{Q}_{\mathrm{i}}=\beta_{0}+\beta_{\mathrm{i}} \operatorname{Ln} \mathrm{X}_{\mathrm{i}}+(\mathrm{vi}-\mu i)
$$

Where $Q \mathrm{i}$ is the $\mathrm{i}$-th estate production, $\beta_{0}$ is intercept, $\beta i$ is the coefficient of the variable $\mathrm{Xi}, \mathrm{Xi}$ is the factor that is expected to influence the production of $\mathrm{Q} i$, vi is the effect of uncontrollable factors and $\mu$ i is the effect of technical inefficiencies. The production function is separated into functions for the plant cane and ratoon cane. Based on the above equation, the plant cane production function is estimated as:

$\operatorname{Ln} \mathrm{Y}=\operatorname{Ln} \mathrm{a}_{0}+\mathrm{a}_{1} \operatorname{Ln} \mathrm{X}_{1}+\mathrm{a}_{2} \operatorname{Ln} \mathrm{X}_{2}+\mathrm{a}_{3} \operatorname{Ln} \mathrm{X}_{3}+$ $\mathrm{a}_{4} \operatorname{Ln} \mathrm{X}_{4}+\mathrm{a}_{5} \operatorname{Ln} \mathrm{X}_{5}+\mathrm{a}_{6} \operatorname{Ln} \mathrm{X}_{6}+\mathrm{a}_{7} \operatorname{Ln} \mathrm{X}_{7}+\mathrm{a}_{8} \operatorname{Ln}$ $\mathrm{X}_{8}+\mathrm{a}_{9} \operatorname{Ln} \mathrm{X}_{9}+\mathrm{a}_{10} \operatorname{Ln} \mathrm{X}_{10}+\mathrm{a}_{11} \operatorname{Ln} \mathrm{X}_{11}+\mathrm{d}_{1} D_{1}+$ $\mathrm{d}_{2} D_{2}+\mathrm{d}_{3} D_{3}+(\mathrm{v} i-\mu i)$.

Where $Y$ is the production of plant cane (tons) and $\mathrm{X}$ are the factors that expected to influence the sugarcane production: $\mathrm{X}_{1}=$ land area (hectare), $\mathrm{X}_{2}=$ ZA fertilizer (tons), $\mathrm{X}_{3}=$ SP36 fertilizer (tons), $X_{4}=$ KCL fertilizer (tons), $X_{5}=$ seeds (tons), $X_{6}=$ ametryn herbicide (liters), $\mathrm{X}_{7}=2.4 \mathrm{D}$ herbicide (liters), $\mathrm{X}_{8}=$ estate labor (man-days), $X_{9}=$ harvest labor (man-days), $\mathrm{X}_{10}=$ mechanization (work machine days), $X_{11}=$ age of cane harvested (months), dummy type of field $\left(D_{1}\right)$ where wetland $(D=1)$ and others $(D=0)$, dummy sugarcane variety $\left(D_{2}\right)$ where Bululawang $(B L)$ variety $(D=1)$ and others $(D=0)$, and dummy HGU land type $\left(D_{3}\right)$ where HGU land $(D=1)$ and not HGU land $(\mathrm{D}=0)$. Then $\mathrm{a}_{0}-\mathrm{a}_{11}=$ coefficient of the variable $\mathrm{X}_{1}-\mathrm{X}_{11}$ and $\mathrm{d}_{1}-\mathrm{d}_{3}=$ coefficient of dummy variable $D_{1}-D_{3}$. The equation for ratoon cane is likely the equation for plant cane, but by eliminating the seed factor $\left(\mathrm{X}_{5}\right)$ because the ratoon cane does not use seed inputs. The equation becomes: 
$\operatorname{Ln} \mathrm{Y}=\operatorname{Ln} \mathrm{a}_{0}+\mathrm{a}_{1} \operatorname{Ln} \mathrm{X}_{1}+\mathrm{a}_{2} \operatorname{Ln} \mathrm{X}_{2}+\mathrm{a}_{3} \operatorname{Ln} \mathrm{X}_{3}+$ $\mathrm{a}_{4} \operatorname{Ln} \mathrm{X}_{4}+\mathrm{a}_{6} \operatorname{Ln} \mathrm{X}_{6}+\mathrm{a}_{7} \operatorname{Ln} \mathrm{X}_{7}+\mathrm{a}_{8} \operatorname{Ln} \mathrm{X}_{8}+\mathrm{a}_{9} \operatorname{Ln} \mathrm{X}_{9}$ $+\mathrm{a}_{10} \ln \mathrm{X}_{10}+\mathrm{a}_{11} \operatorname{Ln} \mathrm{X}_{11}+\mathrm{d}_{1} D_{1}+\mathrm{d}_{2} D_{2}+\mathrm{d}_{3} D_{3}$ $+(v i-\mu i)$.

There are two other variables besides the variables above, they are errors caused by uncontrolled factors (vi) and errors that are triggered by factors that can be controlled and called as the effects of technical inefficiencies ( $\mu \mathrm{i}) . \mu \mathrm{i}$ (technical inefficiency effect) explained by the equation:

$$
\mu \mathrm{i}=\delta_{0}+\delta_{1} \mathrm{Z}_{1}+\delta_{2} \mathrm{Z}_{2}+\delta_{3} \mathrm{Z}_{3}+\delta_{4} \mathrm{Z}_{4}+\delta_{5} \mathrm{D}_{5}
$$

Where $\mu \mathrm{i}$ is the effect of technical inefficiencies and are expected to be influenced by $Z_{1}$ = age (year), $Z_{2}=$ work experience (year), $Z_{3}=$ formal education (year), $\mathrm{Z}_{4}=$ household size (person), and $\mathrm{D}_{5}=$ dummy factor of the rank level of plant officer which are categorized into rank III and above $(D=1)$ and others $(D=0) . \delta_{0}-\delta_{5}=$ coefficient of the variable $\mathrm{Z}_{1}-\mathrm{Z}_{5}$.

According to (Coelli et al., 2005), Frontier 4.1 program will produce the estimation of log-likelihood, gamma $(\gamma)$ and $\Sigma^{2}$ values. According to Battese \& Corra (1977) the log-likelihood value by MLE method should be compared with the log-likelihood value by OLS method. If the log-likelihood value by MLE method is greater than OLS, it means that the production function is good and matches the reality on the estate. The gamma value $(\gamma)$ indicates how much variation in the error term component caused by the inefficiency effect. The value of $\Sigma^{2}$ indicates the distribution of the error term inefficiency ( $\mu \mathrm{i})$. The small value of $\mu$ i means that $\mu \mathrm{i}$ is normally distributed. T-ratio for sigma squared $\left(\Sigma_{2}\right)$ and gamma $(\gamma)$ is also compared with t-tables at 99\%, 95\%, and 90\% level of confidence to test whether they are partially significant to the analysis of frontier production functions.

The stochastic frontier produces two simultaneous conditions that influence the efficiency and inefficiency. Efficiency was measured by the approach from the output side. The measurement of technical efficiency from the output side was the ratio of the observed output to the maximum output. The technical efficiency at each i-th estate in terms of output was measured using the formula (Coelli, 1996):

$\mathrm{TE}_{\mathrm{i}}=\mathrm{E}\left(\mathrm{Yi}^{*} \mid \mathrm{Ui}, \mathrm{Xi}\right) / \mathrm{E}\left(\mathrm{Yi}^{*} \mid \mathrm{Ui}=0, \mathrm{Xi}\right)$

Based on the estimating variables used in this study, the equation becomes: $T E=\frac{E\left(Y * \mid \begin{array}{c}U_{1}, X_{1}, X_{2}, X_{3}, X_{4}, X_{5}, X_{6}, \\ X_{7}, X_{8}, X_{9}, X_{10}, X_{11}, D_{1}, D_{2}, D_{3}\end{array}\right)}{E\left(Y * \mid \begin{array}{l}U_{1}=0, X_{1}, X_{2}, X_{3}, X_{4}, X_{5}, X_{6}, \\ X_{7}, X_{8}, X_{9}, X_{10}, X_{11}, D_{1}, D_{2}, D_{3}\end{array}\right)}$

Where:

$\mathrm{TE}=$ technical efficiency of the $\mathrm{i}$-th estate

$\mathrm{E}\left(\mathrm{Y}^{*} \mid \mathrm{U}_{1}, \mathrm{X}_{1}, \mathrm{X}_{2}, \ldots, \mathrm{D}_{3}=\right.$ observed output $(\mathrm{i}=1,2, \ldots, \mathrm{n})$ E $\left(Y^{*} \mid U_{1}=0, X_{1}, X_{2}, \ldots, D_{3}=\right.$ maximum output $(i=1,2, \ldots, n)$ 
$\mathrm{X}_{1}-\mathrm{X}_{11}$ and $\mathrm{D}_{1}-\mathrm{D}_{3}=$ variables expected affect to output

The value of technical efficiency is between $0 \leq \mathrm{TE} \leq 1$.

\section{RESULTS AND DISCUSSION}

\section{Stochastic frontier production of plant cane}

In this study, the OLS method was not raised because OLS is an estimation of the average production function, while this research focused on the stochastic frontier production function. Analysis of the estimation of the stochastic frontier production function is using Frontier 4.1 software. The estimation results describe the best performance (best practice) at the level of existing technology. The coefficient of inputs variable in stochastic frontier function indicates the value of the production elasticity of the inputs.

As figured in table 1, the estimation result is shown in the intercept value 1.823, which means that if other independent variables are considered to be zero, the amount of sugarcane production is Ln 1.823 or 0.6004 tons.

Table 1. The stochastic frontier function of plant cane production

\begin{tabular}{lcrr}
\hline \multicolumn{1}{c}{ Variable } & Expected coeff -sign & Coefficient & \multicolumn{1}{c}{ T-ratio } \\
\hline Intercept & + & $1.823^{* * *}$ & 8.469 \\
Land area $\left(\mathrm{X}_{1}\right)$ & + & $0.774^{* * *}$ & 29.119 \\
ZA fertilizer $\left(\mathrm{X}_{2}\right)$ & + & $0.005^{*}$ & 1.722 \\
KCL fertilizer $\left(\mathrm{X}_{3}\right)$ & + & $-0.001^{\mathrm{ns}}$ & -0.695 \\
SP36 fertilizer $\left(\mathrm{X}_{4}\right)$ & + & $0.001^{\mathrm{ns}}$ & 0.337 \\
Seed $\left(\mathrm{X}_{5}\right)$ & + & $-0.379^{* * *}$ & -16.628 \\
Ametryn Herbicide $\left(\mathrm{X}_{6}\right)$ & + & $-0.01^{* * *}$ & -3.559 \\
2.4D Herbicide $\left(\mathrm{X}_{7}\right)$ & + & $0.011^{* * *}$ & 4.452 \\
Estate labor $\left(\mathrm{X}_{8}\right)$ & + & $-0.053^{* * *}$ & -3.217 \\
Harvest labor $\left(\mathrm{X}_{9}\right)$ & + & $0.641^{* * *}$ & 23.431 \\
Mechanization $\left(\mathrm{X}_{10}\right)$ & + & $-0.005^{\mathrm{ns}}$ & -0.754 \\
Age of plants harvested $\left(\mathrm{X}_{11}\right)$ & + & $0.016^{\mathrm{ns}}$ & 0.204 \\
Type of field $\left(\mathrm{D}_{1}\right)$ & + & $0.075^{* * *}$ & 3.660 \\
Varieties $\left(\mathrm{D}_{2}\right)$ & + & $-0.098^{* * *}$ & -6.475 \\
HGU land type $\left(\mathrm{D}_{3}\right)$ & + & $0.000178^{\mathrm{ns}}$ & 0.005 \\
Sigma Squared $\left(\Sigma^{2}\right)$ & & $0.024^{* * *}$ & 14.427 \\
Gamma $(\gamma)$ & & $0.124^{*}$ & 1.758 \\
Log-likelihood function OLS & & 239.750 & \\
Log-likelihood function MLE & & 265.881 & \\
LR Test of the one sided error & & 52.261 & \\
\hline
\end{tabular}

Source: Secondary data analysis

*** = significant at $99 \%{ }^{*}=$ significant at $90 \%$

ns $=$ not significant 
Land area $\left(\mathrm{X}_{1}\right)$ significantly influenced the plant cane production with an elasticity value of 0.774 . It means a 1 percent increase in land area with another input is constant (ceteris paribus) will increase production by 0.774 percent. Increasing the land area of plant cane can be done by adding HGU land, by leasing land from owner, by co-working with regional or private companies, or through land conversion from annual crops to sugarcane. The additional land area or extensification is the fastest step in increasing production, but increasing sugarcane land in Java needs to consider in the availability of land because land conversion has the potential to reduce the production of other commodities such as rice, corn, horticulture, and others. It is in line with study by Susilowati \& Tinaprilla (2012) and Mazwan \& Masyhuri (2019).

Harvest labor $\left(\mathrm{X}_{9}\right)$ had a significant effect with an elasticity value of 0.641 , meaning that a 1 percent increasing of these input and ceteris paribus will increase production by 0.641 percent. Harvest labor became a significant variable because in the sugarcane harvesting, almost all work was done by human labor and not by machinery or mechanization. It supports Febrianti et al. (2015) study proclaiming that harvest labor has a significant influence on sugarcane production.
Other variables that significantly affected were ZA fertilizer $\left(\mathrm{X}_{2}\right)$ with elasticity value of 0.005 and $2.4 \mathrm{D}$ herbicide $\left(\mathrm{X}_{7}\right)$ with elasticity value of 0.011 . Adding 1 percent of $X_{2}$ and $X_{7}$ (separately) will improve the production by 0.005 and 0.011 percent respectively, so it is necessary to pay attention to the costs before adding these inputs. According to Pakpahan \& Purwono (2018), ZA fertilizer contains high nitrogen nutrients so it can increase the weight of the yield of sugarcane and ultimately can increase sugarcane productivity. Therefore, many farmers apply ZA fertilizer more than other fertilizers. There were some variables with negative elasticity value and significant, they are seed $\left(\mathrm{X}_{5}\right)$, ametryn herbicide $\left(\mathrm{X}_{6}\right)$ and estate labor $\left(\mathrm{X}_{8}\right)$. It shows that the use of these inputs is excessive and must be reduced. The number of seeds used in this study was 7.86 tons/ha which according to the study, the amount should reduced. In conventional system prevailing in India, about 6 - 8 tons seed cane/ha (nearly $10 \%$ of total produce) is used as planting material, which comprises of about 25-30 $\mathrm{cm}$ stalk pieces having 2-3 buds (Jain et al., 2010). The amount of ametryn used in this study was 3.73 liters/ha. Compared to the studies undergone by Puspitasari et al. (2013), the use of ametryn should be reduced. Puspitasari et al. (2013) stated that the use of a single herbicide ametryn (dose 3 liters/ha) once or twice 
is more effective in controlling weeds and able to increase the vegetative growth of sugarcane.

Some dummy variables show the difference in production between $D=1$ and $D=0$. In the type of field $\left(D_{1}\right)$ variable, there was a difference between wetland and others. Wetland production was $7.5 \%$ higher than that of dryland. Dryland soils produced less than wetland because the extension of the stem was not optimal. Based on research by (Mastur, 2016), the level of loss from drought is the greatest in the elongation phase, due to the large water requirement phase to increase the weight of sugarcane, especially for stem elongation. Drought causes changes in important physiological activities starting from closing the stomata to suppress transpiration, decreasing carbon dioxide input, decreasing the amount of chlorophyll, and finally decreasing the rate of net photosynthesis. Likewise with the varieties variable $\left(D_{2}\right)$ where the production of BL was 9.8\% smaller than that of non-BL. Study by Riajaya \& Kadarwati (2016) stated that timely planting using varieties with the appropriate type of land typology will increase the productivity of sugarcane and sugar.

As figured in table 1, the loglikelihood function of MLE in the plant cane was 265.881, while the value of loglikelihood OLS is 239.750. It shows that the production function of the MLE method was good and following the conditions in the estate. Based on the t-test, the sigma squared value $\left(\Sigma^{2}\right)$ showing the distribution of the error term inefficiency ( $\mu$ i) was significant at the $99 \%$ confidence level and the value of sigma squared $\left(\Sigma^{2}\right)$ was 0.024 . It means the data were normally distributed. The gamma value $(\gamma)$ was significant at the $90 \%$ confidence level indicating that the error term is due to inefficiency $(\mu \mathrm{i})$. The gamma coefficient value $(\gamma)$ was 0.124 showing that the effect of technical inefficiency in this study was $12.4 \%$ due to managerial factors (factors that can be controlled by humans) and the rest $(87.6 \%)$ was caused by factors that cannot be controlled by humans, such as weather, climate, pests, and others. Thus, the coefficient of inefficiency parameters in the production function becomes meaningful. The value of the generalizedlikelihood (LR) ratio in the plant cane farm was 52.261, this value is higher than the Kodde and Palm table values of 51.251 which was significant at $90 \%$ level of confidence. This means that there is an effect of efficiency and technical inefficiency of plant cane production.

\section{Stochastic frontier production in ratoon cane}

In ratoon cane, several factors which significantly affected the production were the same as plant 
cane, namely the land area, harvest labor, dummy type of field, and dummy varieties. The difference was in fertilizer where ZA was for plant cane and SP36 was for ratoon cane. It is due to the need for nutrient types for each plant system, in which, it is not the same wherein plant cane. In the initial phase of plant growth (age 1-3 months), nutrients are used in addition to budding and also used for root formation, whereas in ratoon cane, nutrients are only used for budding formation. In the herbicide variable. There was also a difference where for plant cane the effect is $2,4 \mathrm{D}$ herbicide while in ratoon cane is ametryn herbicide. In general, the functions of the two types of herbicides are the same, namely for broadleaf weeds. Research by Puspitasari et al. (2013) stated that the use of a single herbicide ametryn (dose 3 liters/ha), 2,4-D (dose 2 l/ha) and mixed herbicide 2,4-D + ametryn (dose $2 \mathrm{l} / \mathrm{ha}+3 \mathrm{l} / \mathrm{ha}$ ) once or twice was more effective in controlling weeds and able to increase the vegetative growth of sugarcane compared to those without controlling weeds. Weed control using a single herbicide ametryn (dose 3 l/ha) has the same effectiveness as controlling weeds using a mixture of herbicide 2,4-D + ametryn (dose $2 \mathrm{l} / \mathrm{ha}+3 \mathrm{l} / \mathrm{h}$ ). The use of a single herbicide ametryn (dose $3 \mathrm{l}$ / ha) 1 week before tillage and 1 month after planting produces vegetative growth of sugarcane which is better seen from plant height, number of leaves, stem diameter and number of tillers.

The results in table 2 show that the intercept value is 2.461 which means that if other independent variables are considered to be zero, the amount of sugarcane production is Ln 2.461 or 0.9005 tons. Land area $\left(\mathrm{X}_{1}\right)$ significantly influenced the average production with elasticity value of 0.711 . It means that adding 1 percent of input with ceteris paribus will increase production by 0.711 percent. Harvest labor $\left(\mathrm{X}_{9}\right)$ significantly influenced the average production with an elasticity value of 0.508 . This value indicates that the addition of 1 percent of these input with ceteris paribus will increase production by 0.508 percent. According to the analysis, there were some variables with a negative elasticity value and significant. They were estate labor $\left(\mathrm{X}_{8}\right)$ and mechanization $\left(\mathrm{X}_{10}\right)$. The use of labor in this study was 271 mandays/ha. Paramitha (2014) in Mazwan \& Masyhuri (2019) stated that the optimum use of labor for private sugar cane plantations was 479.89 man-days. The use of estate labor was lower than the optimum because, in practice, the work of estate labor was assisted in part by mechanization, wherein this study the machines used was as much as 4.74 hours of engine work. For ratoon plants, mechanization was used in the soil piling 
activity. This shows that the rational decision is to reduce its use and adjusted to the needs.

Some dummy variables show the difference in production between $\mathrm{D}=1$ and $\mathrm{D}=0$. In the type of field $\left(\mathrm{D}_{1}\right)$ variable, there is a difference between wetland and others. Wetland production was $16.6 \%$ higher than that of dryland. Likewise with the varieties variable $\left(D_{2}\right)$ where the production of BL was $7.2 \%$, smaller than that of non-BL. The HGU land type shows that HGU land production was $26.3 \%$ greater than that of the others. The HGU land productivity was 66.87 tons/ha and the others were 62.05 tons/ha. HGU productivity was $7.7 \%$ greater than the others.

As figured in table 2, the loglikelihood function of the MLE in the ratoon cane was 213.691, while the value of the log-likelihood MLE was 187.802. It shows that the production function with the MLE method in the ratoon cane is good and following the conditions in the estate. Table 2 shows that based on the t-test, the sigma squared $\left(\Sigma^{2}\right)$ value was significant at the $99 \%$ confidence level and the value of

Table 2. The stochastic frontier function of ratoon cane production

\begin{tabular}{lcrr}
\hline \multicolumn{1}{c}{ Variable } & Expected coeff- sign & Coefficient & \multicolumn{1}{c}{ T-ratio } \\
\hline Intercept & + & $2.461^{* * *}$ & 9.976 \\
Land area $\left(\mathrm{X}_{1}\right)$ & + & $0.711^{* * *}$ & 40.508 \\
ZA fertilizer $\left(\mathrm{X}_{2}\right)$ & + & $0.001^{\mathrm{ns}}$ & 0.205 \\
KCL fertilizer $\left(\mathrm{X}_{3}\right)$ & + & $0.002^{\mathrm{ns}}$ & 0.977 \\
SP36 fertilizer $\left(\mathrm{X}_{4}\right)$ & + & $0.007^{* * *}$ & 3.841 \\
Ametryn Herbicide $\left(\mathrm{X}_{6}\right)$ & + & $0.011^{* * *}$ & 4.880 \\
2.4D Herbicide $\left(\mathrm{X}_{7}\right)$ & + & $0.003^{\mathrm{ns}}$ & 1.145 \\
Estate labor $\left(\mathrm{X}_{8}\right)$ & + & $-0.221^{* * *}$ & -25.967 \\
Harvest labor $\left(\mathrm{X}_{9}\right)$ & + & $0.508^{* * *}$ & 24.159 \\
Mechanization $\left(\mathrm{X}_{10}\right)$ & + & $-0.009^{* * *}$ & -4.615 \\
Age of plants harvested $\left(\mathrm{X}_{11}\right)$ & + & $0.081^{\mathrm{ns}}$ & 1.040 \\
Type of field $\left(\mathrm{D}_{1}\right)$ & + & $0.166^{* * *}$ & 9.907 \\
Varieties $\left(\mathrm{D}_{2}\right)$ & + & $-0.072^{* * *}$ & -5.228 \\
HGU land type $\left(\mathrm{D}_{3}\right)$ & + & $0.263^{* * *}$ & 9.341 \\
Sigma Squared $\left(\Sigma^{2}\right)$ & + & $0.037^{* * *}$ & 5.542 \\
Gamma $(\gamma)$ & & $0.028^{\mathrm{ns}}$ & 0.110 \\
Log-likelihood function OLS & + & 187.802 & \\
Log-likelihood function MLE & + & 213.691 & \\
LR Test of the one sided error & & 51.778 & \\
\hline
\end{tabular}

Source: Secondary data analysis

*** = significant at 99\%

ns $=$ not significant 
the sigma squared $\left(\Sigma^{2}\right)$ was 0.037 . It means that data were normally distributed. The gamma coefficient value $(\gamma)$ was 0.028 . It indicates that the technical inefficiency in this study was $2.8 \%$ due to managerial factors and the rest (97.2\%) was affected by factors that cannot be controlled by humans. The value of gamma $(\gamma)$ which is close to 0 , means that the error term mostly comes from noise (vi) and not due to inefficiency $(\mu \mathrm{i})$. The gamma value $(\gamma)$ was not significant at any level of confidence which indicates that the error term was not due to inefficiency ( $\mu \mathrm{i})$. Thus, the coefficient of inefficiency parameters in the production function becomes meaningless. Generalized-likelihood (LR) ratio value in ratoon cane farming is 51.777, this value was higher than Kodde and Palm table values of 51.251 which was significant at a $90 \%$ level of confidence.

\section{The level of efficiency in owned-by- company sugarcane production}

Table 3 appears that the average technical efficiency of the plant cane was 0.9621 with the lowest value is 0.7140 and the highest is 0.9939 . This means that the average plant cane production achieved 96.21 percent of the frontier, which was the maximum production that can be achieved with the best management system (the best practice). In the short term, plant cane production had the opportunity to increase by 3.20 percent (1(0.9621/0.9939)). Similar conditions also occur in ratoon cane farming. In the ratoon cane production, the average technical efficiency was 0.9456 with the lowest value was 0.7934 and the highest was 0.9962 . This means that the average of ratoon cane production achieved 94.56 percent of the frontier. In the short term, ratoon cane farming has the opportunity to increase by 5.08 percent $(1(0.9456 / 0.9962))$. It is in line with the study by (Setyawati \& Wibowo, 2019) that technical efficiency of plant cane farming is more efficient than that of ratoon cane farming.

The combined technical efficiency of plant and ratoon cane was 0.9518 . Referring to Coelli et al. (1998) that production has been efficient if its efficiency value is greater or equal to 0.70. It is means that the efficiency of owned-by-company sugarcane production is technically efficient. In the short term, the average of ownedby-company sugarcane farming had the opportunity to increase by 4.45 percent (1-(0.9518/ 0.9962)).

According to Puruhito et al. (2019), a high value of technical efficiency means two notions. First, high technical efficiency shows that the ability of farmers to manage the crops is quite high.

Second, it shows that the opportunity to increase actual production according to its potential production 
Table 3. The distribution of technical efficiency of sugarcane production

\begin{tabular}{crrrrrr}
\hline \multirow{2}{*}{\begin{tabular}{c} 
The distribution $\begin{array}{c}\text { Plant cane } \\
\text { of index }\end{array}$ \\
\cline { 2 - 7 }
\end{tabular}} & Number of estate & $\%$ & $\begin{array}{r}\text { Number of } \\
\text { estate }\end{array}$ & $\%$ & $\begin{array}{r}\text { Number of } \\
\text { estate }\end{array}$ & $\%$ \\
\hline$<0.70$ & 0 & 0 & 0 & 0 & 0 & 0 \\
$0.70-0.80$ & 14 & 2.64 & 4 & 0.46 & 18 & 1.28 \\
$0.80-0.90$ & 38 & 7.16 & 121 & 13.86 & 159 & 11.32 \\
$0.90-1$ & 479 & 90.21 & 748 & 85.68 & 1227 & 87.39 \\
\hline Total & 531 & 100 & 873 & 100 & 1404 & 100 \\
Average & 0.9621 & & 0.9456 & & 0.9518 \\
Minimum & 0.7140 & & 0.7934 & & 0.7140 \\
Maximum & 0.9939 & & 0.9962 & & 0.9962 \\
\hline
\end{tabular}

Source: Secondary data analysis

Table 4. The Estimation Factors which Affect the Technical Inefficiency

\begin{tabular}{lcrrrrrr}
\hline \multirow{2}{*}{ Variable } & \multirow{2}{*}{$\begin{array}{c}\text { Expec-ted } \\
\text { coeff sign }\end{array}$} & \multicolumn{3}{c}{ Clant cane } & \multicolumn{3}{c}{ Ratoon cane } \\
\cline { 3 - 8 } & & $\begin{array}{r}\text { Coff- } \\
\text { error }\end{array}$ & T-ratio & Coeff- & $\begin{array}{r}\text { Std. } \\
\text { error }\end{array}$ & T-ratio \\
\hline Intercept & + & $0.794^{\text {ns }}$ & 0.731 & 1.086 & $-1.299^{*}$ & 0.683 & -1.903 \\
Age $\left(\mathrm{Z}_{1}\right)$ & + & $0.134^{\text {ns }}$ & 0.165 & 0.812 & $0.457^{* * *}$ & 0.113 & 4.045 \\
Work experience $\left(\mathrm{Z}_{2}\right)$ & + & $0.06^{\text {ns }}$ & 0.063 & 0.951 & $-0.102^{* * *}$ & 0.015 & -6.995 \\
Formal education $\left(\mathrm{Z}_{3}\right)$ & + & $-0.79^{* * *}$ & 0.162 & -4.892 & $-0.184^{* * *}$ & 0.055 & -3.314 \\
Household size $\left(\mathrm{Z}_{4}\right)$ & + & $0.038^{\text {ns }}$ & 0.031 & 1.245 & $0.052^{* *}$ & 0.021 & 2.459 \\
$\begin{array}{l}\text { Rank level } \\
\text { of plant officer }\left(\mathrm{D}_{5}\right)\end{array}$ & + & $0.744^{* * *}$ & 0.151 & 4.918 & $0.403^{* * *}$ & 0.143 & 2.819 \\
\hline
\end{tabular}

Source: Secondary data analysis

${ }^{* * *}=$ significant at $99 \%,{ }^{* *}=$ significant at $95 \% ;^{*}=$ significant at $90 \%$ ns $=$ not significant

becomes smaller. In this study, the opportunity to increase production was $4.45 \%$. Therefore, to increase sugarcane production, land extensification and increasing the production inputs are needed.

\section{Factors affecting production inefficiency}

As figured in table 4, in plant cane the variables having significant influence were the formal education and rank level of plant officer. The formal education variable significantly influenced the effect of plant cane inefficiency. The coefficient of formal education was a negative value, indicating the longer of the formal education of a plant officer, the higher the efficiency of sugarcane production and the level of inefficiency can be lower. It is in line with the study by Tinaprilla (2011) and Zainuddin \& Wibowo (2018) that variables influencing the inefficiency 
of sugarcane farming was the level of education. The dummy variable rank level of plant officer was significant and had a positive value. It means that the higher the plant officer rank level, the higher inefficiency will be.

In ratoon cane, based on the results of the estimation of the MLE production function, there was no effect of inefficiency there so that the coefficient of inefficiency was meaningless. Increased production on ratoon cane can be done through increased production factors, including increasing land area, increasing the use of SP36 fertilizer, ametryn herbicide and harvest labor. The expansion of wetland and the addition of HGU land can also be done to increase the production of ratoon cane. On the other hand, an increase in ratoon cane production can be done by improving ratoon maintainence techniques which are in accordance to Kadarwati et al. (2015) research proclaiming that it can increase productivity by 16.20 tons/ha.

\section{CONCLUSION AND SUGGESTION}

Factors affecting the increase of production of plant cane were land area, ZA fertilizer, harvest labor, and type of fields (wetland or others) while dummy varieties affected plant cane production, making it decrease. Factors affecting the production of ratoon cane were land area, SP36 fertilizer, ametryn herbicide, harvest labor, type of fields, and HGU land type, while estate labor, mechanization, and dummy varieties affect decreasing ratoon cane production.

The average value of efficiency of the plant cane was 0.9621 and ratoon cane was 0.9456 . The poll value of efficiency was 0.9518 . The level of efficiency was at the efficient category. The technical efficiency of plant cane farming is more efficient than that of ratoon cane farming.

Factors affecting production inefficiency for the plant cane are formal education and rank levels of plant officer. However the coefficient of the formal education variable was negative and the rank level coefficient was positive. A higher level of education will increase production, but a higher rank level of plant officer will decrease it. In ratoon cane, there was no effect of technical inefficiency. So, an increase in ratoon cane production can be done by increasing the use of production input or by ratoon maintain techniques.

Inefficiencies in the production of plant cane can be reduced by increasing the level of education of plant officer. Improved education levels can be provided by giving mentoring or the provision of courses. Another thing that can be done is by allowing plant officer to benchmark to other similar companies. 


\section{REFERENCES}

Battese, G. E., \& Corra, G. S. (1977). Estimation of a Production Frontier Model: With Application To the Pastoral Zone of Eastern Australia. Australian Journal of Agricultural Economics, 21(3), 169-179. https://doi. org/10.1111/j.1467-8489.1977. tb00204.x

Coelli, T. J. (1996). A Guide to FRONTIER Version 4.1: A Computer Program for Stochastic Frontier Production and Cost Function Estimation. CEPA Working Papers, 7, 1-33. https:// doi.org/10.1007/BF00158774

Coelli, T. J., Rao., D. S. P., \& Battese, G. E. (1998).AnIntroduction to Efficiency and Productivity Analysis. Boston: Kluwer Academic Publishers.

Coelli, T. J., Rao., D. S. P., O’Donnel, C. J., \& Batesse, G. E. (2005). An Introduction to Efficiency and Productivity Analysis. Second edition (2nd ed.). New York: Springer Science-i-Business Media, Inc.

Fahriyah, F., Hanani, N., Koestiono, D., \& Syafrial, S. (2018). Analisis Efisiensi Teknis Usahatani Tebu Lahan Sawah dan Lahan Kering dengan Pendekatan Data Envelopment Analysis (DEA).
Jurnal Ekonomi Pertanian Dan Agribisnis (JEPA), 2(1), 77-83. https://doi.org/10.21776/ ub.jepa.2018.002.01.8

Febrianti, D. I., Jamhari, J., \& Hartono, S. (2015). Efisiensi Usaha Tani Tebu di Kabupaten Purworejo. Jurnal Agro Ekonomi, 26(1), 1-9.

Gideon, A. (2019). Rendahnya Produktivitas Tebu Bikin Impor Gula Melambung. Retrieved December 23, 2019, from liputan6.com website: https:// www.liputan6.com/bisnis/ read/3875078/rendahnyaproduktivitas-tebu-bikin-imporgula-melambung

Jain, R., Solomon, S., Shrivastava, A. K., \& Chandra, A. (2010). Sugarcane bud chips: A promising seed material. Sugar Tech, 12(1), 67-69. https:// doi.org/10.1007/s12355-0100013-9

Kadarwati, F. T., Santoso, B., \& Khuluq, A. D. (2015). Peningkatan Produksi dan Rendemen Tebu Melalui Rawat Ratoon. Jurnal Litri, 21(4), 199205.

Kementerian Pertanian. (2016). Outlook Tebu. Pusat Data Dan Sistem Informasi Pertanian, 84. 
Mastur, M. (2016). Respon Fisiologis Tanaman Tebu Terhadap Kekeringan. Buletin Tanaman Tembakau, Serat \& Minyak Industri, 8(2), 98-111. https:// d oi .org/10.21082/btsm. v8n2.2016.99-112

Mazwan, M. Z., \& Masyhuri, M. (2019). Alokasi Penggunaan Input Produksi Tebu Perkebunan Rakyat di Jawa Timur (Studi Kasus Petani Tebu Plasma PTPN XI). Jurnal Ekonomi Pertanian Dan Agribisnis (JEPA), 3(1), 138151. https://doi.org/10.21776/ ub.jepa.2019.003.01.14

Nusantara Sugar Community. (2017). Kinerja Industri Gula Nasional Tahun 2013-2017. Jurnal Gula. 51(7), 62.

Pakpahan, F. P., \& Purwono, P. (2018). Pengelolaan Tanaman Tebu (Saccharum officinarum L.) di Wilayah PG Madukismo dengan Aspek Korelasi Pemupukan terhadap Produktivitas. Buletin Agrohorti, 6(3), 336-343. https://doi.org/10.1017/ CB09781107415324.004

Puruhito, D. D., Jamhari, J., Hartono, S., \& Irham, I. (2019). Technical Efficiency and Sources of
Inefficiency in Smallholder Oil Palm Plantation in North Mamuju District, West Sulawesi Province, Indonesia. AmericanEurasian Journal of Sustainable Agriculture, 13(1), 1-8. https://doi. org/10.22587/aejsa.2019.13.1.1

Puspitasari, K., Sebayang, H. T., \& Guritno, B. (2013). Pengaruh Aplikasi Herbisida Ametrin Dan 2, 4-D Dalam Mengendalikan Gulma Tanaman Tebu ( Saccharum Officinarum L .). Jurnal Produksi Tanaman, 1(2), 72-80.

Riajaya, P. D., \& Kadarwati, F. T. (2016). Kesesuaian Tipe Kemasakan Varietas Tebu pada Tipologi Lahan Bertekstur Berat, Tadah Hujan, dan Drainase Lancar. Buletin Tanaman Tembakau, Serat \& Minyak Industri, 8(2), 85-97.

Setyawati, I. K., \& Wibowo, R. (2019). Efisiensi Teknis Produksi Usahatani Tebu Plant Cane dan Tebu Ratoon Cane (Studi Kasus di PT. Perkebunan Nusantara X). Journal of Social and Agricultural Economics (JSEP), 12(1), 80-99.

Susilowati, S. H., \& Tinaprilla, N. (2012). Analisis Efisiensi Usaha Tani Tebu Di Jawa Timur. Jurnal Littri, 18(4), 162-172. https:// 
doi.org/ 10.21082 /littri. v18n4.2012.162

Tinaprilla, N. (2011). Analisis Efisiensi Teknis Usahatani Tebu Di Jawa Timur. In R. Nurmalina, W. B. Priatna, S. Jahroh, P. Nurhayati, \& A. Rifin (Eds.), Prosiding Seminar - Penelitian Unggulan Departemen Agribisnis (pp. 51-78). Bogor: Departemen Agribisnis Fakultas
Ekonomi dan Manajemen Institut Pertanian Bogor.

Zainuddin, A., \& Wibowo, R. (2018). Analisis Potensi Produksi Tebu dengan Pendekatan Fungsi Produksi Frontir di PT Perkebunan Nusantara X. Jurnal Pangan, 27(1), 33-42. Retrieved from http://www. jurnalpangan.com/index.php/ pangan/article/view/404\%09 